\title{
BUILDING LEARNING CULTURE TOWARDS A LEARNING ORGANIZATION TO EMPOWER EMPLOYEE'S KNOWLEDGE
}

\author{
Maryani; Marihut Donna; Nilam Hapsari \\ Jurusan Komputerisasi Akuntansi, Fakultas Ilmu Komputer, Universitas Bina Nusantara \\ Jln. K.H. Syahdan No. 9, Palmerah, Jakarta Barat 11480 \\ yanie@binus.edu
}

\begin{abstract}
This paper contains the application of knowledge management in PT Unilever to create a learning culture within the organization. Which consists of: knowledge sharing, informal sharing, online sharing and other sources. With the implementation of cultural sharing between employees, the module is already owned by PT Unilever as many as 250 modules. With the application of Knowledge Management PT Unilever awarded a global level, the Most Admired Knowledge Enterprise (MAKE) Award in the year 2005-2007 to the level of Indonesia and 2008 for the Asian level. In the end, knowledge-owned companies, creating a good performance by individuals or companies, and will create sustainable growth for the company. Sustainable growth is what is expected by the whole company in running its business activities.
\end{abstract}

Keywords: adminKnowledge management, learning organization, employee

\begin{abstract}
ABSTRAK
Paper ini berisi mengenai penerapan knowledge management dalam PT Unilever untuk menciptakan budaya belajar dalam organisasi. Yang terdiri dari : knowledge sharing, informal sharing, online sharing dan other sources. Dengan penerapan budaya sharing antar karyawan, modul yang sudah dimiliki oleh PT Unilever sebanyak 250 modul. Dengan penerapan Knowledge Management PT Unilever mendapatkan penghargaan tingkat dunia, yaitu Most Admired Knowledge Enterprise (MAKE) Award pada tahun 2005-2007 untuk tingkat Indonesia dan 2008 untuk tingkat Asia. Pada akhirnya, knowledge yang dimiliki perusahaan, menciptakan performance baik secara individu maupun perusahaan, kemudian akan menciptakan sustainable growth bagi perusahaan. Pertumbuhan perusahaan yang berkelanjutan inilah yang diharapkan oleh seluruh perusahaan dalam menjalankan kegiatan bisnisnya
\end{abstract}

Kata kunci: Knowledge management, budaya balajar, karyawan 


\section{PENDAHULUAN}

Belajar bukan hanya dilakukan saat kita benar-benar sedang berada di bangku sekolah maupun perguruan tinggi. Ketika kita memasuki dunia kerja, justru proses belajar tersebut akan benar-benar terasa dan kita akan menyadari benar manfaat dari proses belajar tersebut. Bagaimana perusahaan menciptakan budaya belajar dan memfasilitasi karyawannya dalam proses belajar?Dalam paper ini dijelaskan mengenai alasan mengapa sebuah organisasi harus belajar dan berubah, pengertian dari learning organization, bagaimana perusahaan menciptakan budaya belajar di dalam lingkungan organisasinya. Selain itu dibahas pula bagaimana membuat proses pembelajaran yang menarik bagi karyawan, dan juga bagaimana budaya belajar tersebut dapat menjadi sebuah competitive advantage bagi perusahaan.

Sebuah kutipan yang ditulis oleh Alvin Toffler yang berbunyi "the illiterate of 21th century will not be those who cannot read and write, but those who cannot learn, unlearn and relearn". Kebodohan di abad 21 seperti saat ini bukan lagi diakibatkan oleh buta huruf semata, tetapi oleh orang-orang yang tidak mau belajar, tidak mau membuang pengetahuan yang salah yang selama ini diyakininya dan juga tidak mau mempelajari kembali apa yang telah dipelajari sebelumnya. Oleh karena itu, walaupun kita sangat terampil dalam membaca dan menulis, namun jika kita tidak mau belajar, maka jangan-jangan kita termasuk dalam kategori orang-orang yang bodoh dalam definisi Toffler di atas.

\section{Landasan Teori}

\section{Mengapa Organisasi Perlu Belajar?}

Sama seperti kita pribadi yang perlu terus belajar, perusahaan juga memiliki beberapa alasan mengapa ingin terus maju dan perlu untuk belajar, antara lain:

\section{a. Kompetisi Yang Semakin Ketat (Intense Business Competition)}

Kompetisi dalam kegiatan bisnis sekarang ini semakin ketat, dan perusahaan dituntut untuk menjadi sebuah organisasi pembelajar dan melakukan perubahan sesuai dengan keadaan lingkungannya. Jim Collins dalam bukunya Good To Great menyatakan bahwa sebuah perusahaan yang sudah baik (good) harus lebih banyak belajar lagi untuk bisa menjadi lebih baik lagi (great). Terkadang, perusahaan yang sudah merasa baik (good) lantas cepat berpuas diri, sehingga tidak ingin menjadi lebih baik lagi (great). Hal ini justru akan memicu perusahaan mengalami masa kemunduran. Proses pembelajaran yang telah mereka tempuh dapat dipelajari oleh para pesaing yang ada yang kemudian dapat mengalahkan perusahaan yang sudah baik tadi.

b. Sinergi Antar Anggota Tim (Synergy among Member)

Dalam menjalankan kegiatannya, perusahaan diharuskan memiliki sinergi antar departemen yang satu dengan yang lain, agar dapat mencapai tujuan perusahaan. Misalnya, departemen produksi dan pemasaran harus memiliki sinergi yang baik, agar dapat menghasilkan output yang berkualitas dan tentunya dapat menguntungkan perusahaan.

\section{c. Perubahan Yang Sangat Cepat (Rapid Changes)}

Karena perubahan semakin cepat terjadi, perusahaan diharapkan selalu melakukan perubahan dan peka terhadap perubahan yang terjadi di lingkungan usahanya.

d. Mengantisipasi Masa Depan Yang Penuh Ketidakpastian (Anticipate Future \& Uncertainty)

Perusahaan melakukan pembelajaran dan perubahan untuk mengantisipasi masa depan dan ketidakpastian yang akan terjadi di masa datang. Dengan beberapa alasan seperti di atas, maka dapat disimpulkan bahwa hanya perusahaan yang fleksibel, adaptif dan produktif yang dapat berkembang dan tampil menjadi pemenang. Perusahaan yang seperti itulah juga yang mampu menjadi sebuah organisasi pembelajar (learning organization). 


\section{Apakah Learning Organization itu?}

Definisi dari learning organization yang cukup mewakili setidaknya dapat dijelaskan dari dua sumber rujukan berikut:

1. Peter Senge (1990 : 3) dari buku The Fifth Discipline

Peter Senge dalam karyanya yang terkenal memberi definisi Learning Organization sebagai "...organizations where people continually expand their capacity to create the results they truly desire, where new and expansive patterns of thinking are nurtured, where collective aspiration is set free, and where people are continually learning to see the whole together."

Ada beberapa kata kunci di sana yakni: Senantiasa meningkatkan kemampuan dan kapasitas, Pemikiran baru dan luas diberi kesempatan tumbuh, Aspirasi bersama diberi kebebasan berkembang dan Orang-orang yang terus menerus belajar

2. Mike Pedler, dkk (1997) dari buku The Learning Company

Learning Organization adalah: "...an organization that facilitates the learning of all its members and continuously transforms itself."

Peran organisasi adalah memberikan fasilitasi atau dukungan kepada seluruh anggotanya terkait proses pembelajaran sehingga orang-orang di dalam organisasi tersebut maupun organisasi itu sendiri dapat terus bertransformasi ke arah yang lebih baik secara kontinyu, terus menerus.

\section{Komponen Learning Organization}

Dalam buku yang sama, yaitu The Fifth Discipline, karya Peter Senge, menyebutkan ada 5 komponen learning organization, yaitu :

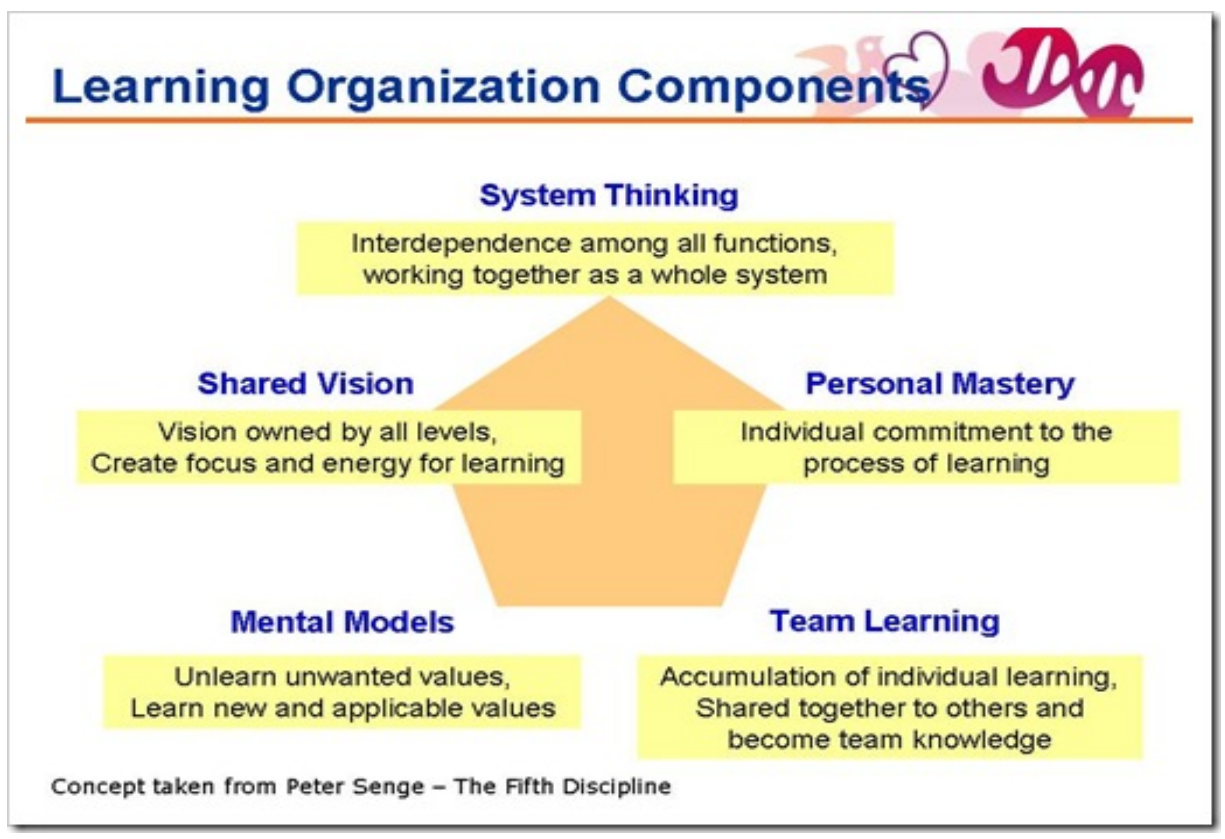

Gambar 1.Komponen Learning Organization

\section{System Thinking}

Kita harus melihat segala sesuatu yang ada di perusahaan sebagai sebuah kesatuan, bukan sesuatu yang bersifat individual.

\section{Shared Vision}

Sebagai pemimpin, pasti memiliki visi tersendiri yang belum tentu dimiliki oleh para anak 
buahnya. Oleh sebab itu, perusahaan memfasilitasi dan mengatur agar terjadi sinergi antara visi yang dimiliki oleh sang pemimpin dengan para anak buahnya.

\section{Personal Mastery}

Komponen ini meliputi keinginan atau komitmen yang muncul dari seseorang untuk melakukan pembelajaran. Biasanya, seseorang tumbuh dan belajar di bidang yang ia minati dan menjadi bidang inti (core) dalam proses pembelajarannya.

\section{Mental Methods}

Secara mental, jika ada nilai-nilai yang tidak sesuai dengan proses pembelajaran dalam sebuah organisasi, maka harus ada nilai-nilai baru yang sesuai untuk dimasukkan ke dalamnya.

\section{Team Learning}

Setiap individu memiliki pengetahuan dan pengalaman tersendiri, dan hal ini haruslah dibagikan kepada orang lain agar menjadi sebuah tim yang dapat menghasilkan pengetahuan bersama di sebuah organisasi.

\section{Hambatan dalam Proses Sharing/Belajar}

Di dalam sebuah learning organization, kegiatan sharing biasa dilakukan, untuk memberikan pengetahuan kepada orang lain, dan tentunya ini merupakan suatu proses belajar yang cukup efektif, karena seseorang dapat belajar dari pengalaman orang lain. Namun, kegiatan sharing ini juga tidak semudah itu dilaksanakan oleh perusahaan, ada beberapa hal yang dapat menghambat proses sharing, antara lain:

Hambatan individu:

\section{Pengetahuan adalah kekuatan (Knowledge is power)}

Pengetahuan dianggap sebagai sebuah kekuatan tersendiri. Pengetahuan yang dimiliki oleh seseorang menjadi sebuah kekuatan tersendiri, dan jika harus dibagikan kepada orang lain, justru akan merugikan dirinya, karena akan merasa tersaingi.

\section{Tidak terlibat di dalamnya (Not invented here)}

Setiap orang memiliki cara belajar tersendiri, sehingga jika ia merasa bukan cara belajar yang ia ciptakan, maka ia tidak mau belajar.

3. Kurangnya kesadaran karyawan mengenai pentingnya belajar

Karyawan juga terkadang belum menyadari pentingnya kegiatan belajar di perusahaan. Mereka menganggap bahwa proses belajar tersebut tidak memberikan manfaat bagi mereka dan hanya menguras waktu dan tenaga mereka saja. Waktu yang digunakan untuk melakukan suatu pekerjaan tidak sedikit, sehingga terkadang karyawan merasa kekurangan waktu untuk bisa belajar.

Hambatan organisasi:

\section{Kurangnya dukungan dari manajemen (Lack of support from management)}

Banyak organisasi yang tidak memfasilitasi para karyawannya untuk belajar. Perusahaan tersebut menganggap bahwa dengan belajar justru akan mengurangi produktivitas kerja karena mengurangi jam kerja para karyawan.

2. Budaya organisasi tidak bersahabat dengan proses pembelajaran

Budaya organisasi yang tidak bersahabat dengan proses pembelajaran

\section{Kegiatan belajar (sharing) itu sendiri bukan merupakan cara kerja organisasi}

\section{Perubahan Paragdima}

Sekarang ini terjadi pergeseran paradigma mengenai proses belajar yang ada di perusahaan. Cara baru yang muncul adalah, bahwa trainer tidak selalu harus berasal dari luar perusahaan, proses belajar dapat dilakukan dimana dan kapan saja, serta setiap orang harus bertanggung jawab akan proses belajar tersebut, bukan hanya menjadi tanggung jawab HR Department. Jadi kita harus dapat mengubah paradigma dari belajar gaya lama dengan belajar gaya baru. 
Pendekatan lama diantaranya:

1. Kegiatan pembelajaran/pelatihan hanya ada di ruang kelas, 2. Pelatihan adalah tanggung jawab, 3 . bagian Sumber Daya Manusia (HR), 4. Pelatihan dan pembelajaran harus serius dan formal, 5. Ilmu yang didapat disimpan untuk diri sendiri, 6. Tergantung pada fasilitator atau trainer dari luar organisasi, 7. Kegiatan Belajar adalah kewajiban dan ditentukan oleh pimpinan, 8. Kegiatan pelatihan hanya untuk mengatasi kebutuhan saat ini, 9. Kegiatan pelatihan/pembelajaran tergantung jadwal dan penugasan yang telah ditentukan. Adapun pendekatan baru yang harus mulai diadopsi oleh organisasi yang ingin menumbuhkan budaya belajar diantaranya: Kegiatan pembelajaran/pelatihan dapat dilakukan kapan saja dan di mana saja, Setiap orang bertanggung jawab, baik dalam departemen maupun sebagai individu, Kegiatan belajar harus menyenangkan, mudah, dan menarik, Ilmu untuk dibagi agar tumbuh dan berkembang bersama-sama, Menciptakan internal trainer dan fasilitator di dalam organisasi, Proses belajar adalah pilihan pribadi untuk pengembangan pribadi, Belajar untuk menghadapi tantangan di masa yang akan datang, Belajar dilakukan secara terus menerus untuk memperkaya diri dengan pengetahuan baru yang relevan dengan perubahan dan tantangan zaman

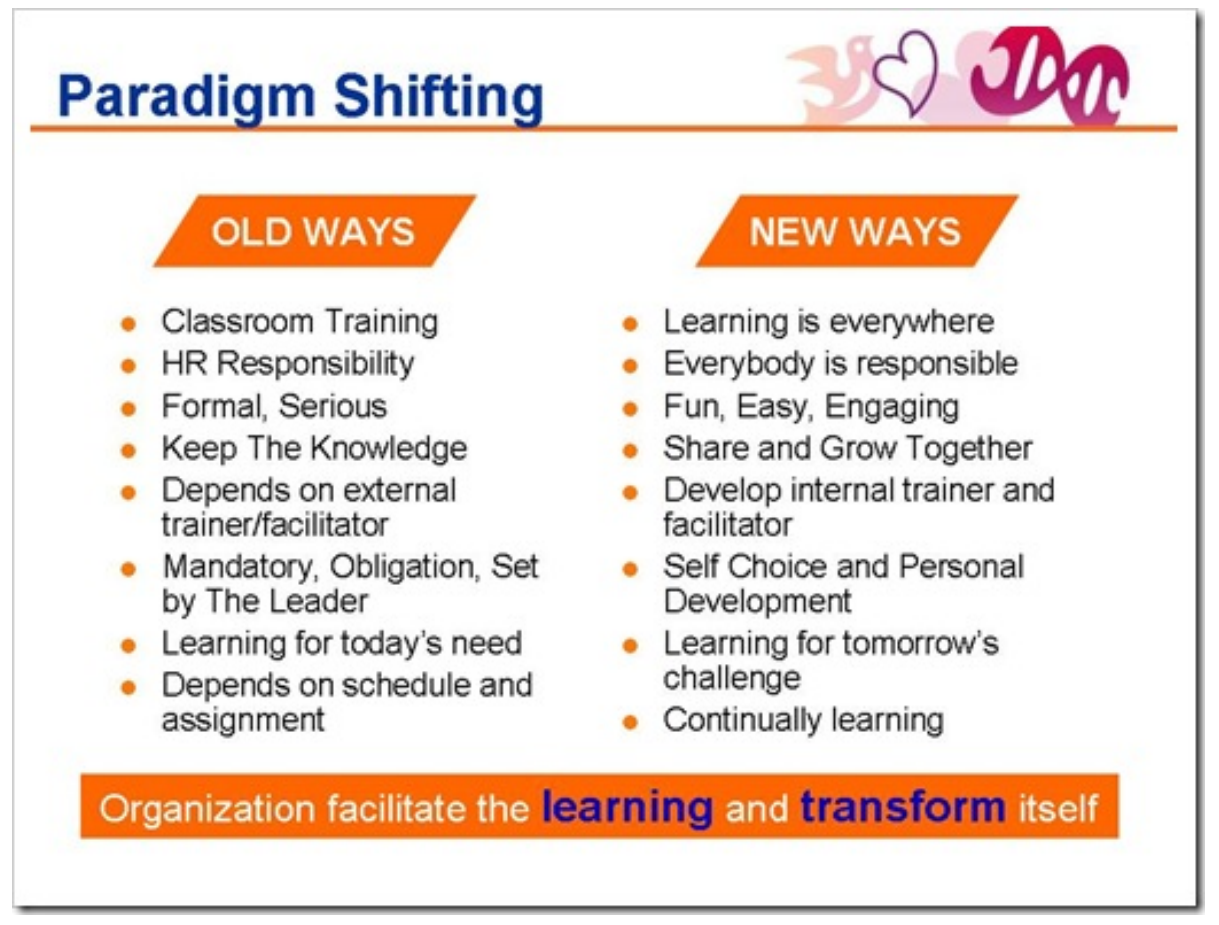

Gambar 2. Paradigma pembelajaran

Proses belajar yang baik dan efektif terjadi ketika keinginan untuk belajar tersebut muncul dari dalam diri seseorang, bukan datang dari paksaan perusahaan. Jika perusahaan hanya memaksakan para karyawannya untuk mengikuti kegiatan training misalnya, tanpa didukung oleh kemauan pribadi maka training tersebut akan menjadi sia-sia, karena si karyawan merasa telah menyelesaikan kewajibannya saja. Tentu saja, pengetahuan dan ilmu yang diperoleh akan menguap begitu saja. Hal ini akan berbeda jika keadaan si karyawan memang memiliki rasa ingin tahu dan rasa ingin belajar, maka ilmu dan pengetahuan yang diperoleh akan masuk ke dalam pikiran mereka dan training tersebut menjadi lebih efektif.

Peran sebuah organisasi dalam proses pembelajaran ini adalah memfasilitasi proses belajar tersebut dan membantu terjadinya perubahan yang semula sulit menjadi mudah dan yang baik menjadi berkembang. Penerapan konsep perusahaan sebagai fasilitator dalam proses pembelajaran dapat kita temui di Unilever Indonesia. Berikut merupakan contoh kasus yang ada di Unilever Indonesia (ULI). 


\section{HASIL DAN PEMBAHASAN}

\section{Mengenai PT Unilever Indonesia Tbk}

PT Unilever Indonesia Tbk yang beroperasi di Indonesia sejak tahun 1933, telah tumbuh dan berkembang bersama masyarakat Indonesia selama 75 tahun. Sebagai perusahaan penyedia produk konsumen yang mempunyai peran penting di Indonesia, Unilever adalah produsen merek-merek yang sudah sangat dikenal masyarakat, antara lain Pepsodent, Lifebuoy, Lux, Dove, Sunsilk, Clear, Rexona, Rinso, Molto, Pond's, Citra, Blue Band, Sariwangi, Royco, Bango, Wall's dan masih banyak lagi. Sebagai perusahaan yang telah 'go public' pada akhir tahun 1981 dan sahamnya tercatat dan diperdagangkan di Bursa Efek Indonesia, Unilever memiliki komitmen kuat untuk terus maju bersama Indonesia. Pada periode Januari - September 2008 PT Unilever Indonesia Tbk berhasil meraih pertumbuhan laba bersih $30 \%$ dan mencapai Rp 2,1 trilyun, dengan pertumbuhan penjualan $22 \%$ dan mencapai Rp 11,8 trilyun.

Sebagai perusahaan yang mempunyai tanggung jawab yang tinggi terhadap masyarakat, secara berkelanjutan Unilever menjalankan program tanggung jawab perusahaan (Corporate Social Responsibility/CSR) tidak hanya pada program korporasi, tetapi juga pada brand-brandnya. Beberapa Program sosial masyarakat yang dilakukan Unilever adalah: Kampanye Cuci Tangan dengan Sabun (Lifebuoy), Program Edukasi Kesehatan Gigi dan Mulut (Pepsodent), Program Pelestarian Makanan Tradisional (Bango), Program memerangi kelaparan dan membantu anak Indonesia yang kekurangan gizi (Blue Band) dan masih banyak lagi. Dalam bidang korporasi, di bawah payung Yayasan Unilever Indonesia, Unilever menjalankan tanggung jawab perusahaannya dalam bidang: program pemberdayaan masyarakat/UKM (Program Pemberdayaan Petani Kedelai Hitam), program edukasi kesehatan masyarakat (Pola Hidup Bersih dan Sehat / PHBS), Program Lingkungan (Green and Clean), dan lain-lain.

Posisi Unilever Indonesia yang kuat sebagai pemimpin pasar telah diakui melalui berbagai penghargaan nasional dan internasional yang diterima oleh perusahaan. Pada tahun 2008, Unilever Indonesia menerima 63 penghargaan lokal dan regional baik dari berbagai media massa papan atas maupun instansi pemerintah, antara lain: Asia's 200 Most Admired Companies oleh Wall Street Journal Asia, PROPER Award oleh Kementrian Lingkungan Hidup, 4 penghargaan International Asia's Best Brand Poll (Best Managed Company, Best Corporate Governance, Best Investor Relations \& Most Committed to a Strong Dividend Policy), Energy Globe Award (Environment IDE program), Asian MAKE Award 2008, Indonesia's Best Brand Award oleh SWA, Most Admired Company dari Majalah Warta Ekonomi, nominasi untuk MDG Award kategori pemberdayaan perempuan, oleh PBB dan Metro TV dan lain-lain.

Unilever Indonesia adalah salah satu perusahaan yang sangat peduli akan pentingnya menciptakan budaya belajar. Lewat cara-cara yang menarik dan inovatif, Unilever Indonesia mampu membuat program pelatihan dan pembelajaran menjadi sesuatu yang menyenangkan. Tidak hanya itu, karyawan juga termotivasi untuk selalu menambah ilmu sekaligus memberikan sharing atas apa-apa yang dikuasainya. Lewat cara ini, tercipta budaya belajar dari, oleh dan untuk semua karyawan.

\section{Alasan Unilever Indonesia Harus Menciptakan Budaya Sharing Pengetahuan}

ULI merupakan sebuah perusahaan multinasional yang bergerak di bidang FMCG (Industri Fast Moving Consumer Goods). Dalam perjalanannya, ULI semakin memahami pentingnya sharing culture di dalam perusahaan. Hal ini dikarenakan adanya beberapa alasan yang mendorong ULI untuk mewujudkan budaya tersebut. 
Alasan pertama, secara budaya, cara kerja di ULI adalah saling berkomunikasi dan berkoordinasi antar departemen. Setiap departemen di ULI memiliki fungsi dan tanggung jawabnya masing-masing. Agar departemen-departemen itu dapat mencapai goals perusahaan, maka dibutuhkan sistem komunikasi dan kolaborasi antar departemen.

Kedua, ULI merupakan sebuah perusahaan yang bergerak di bidang FMCG yang sangat dinamis, dan konsumen sangat mudah untuk melakukan switching buying. Contohnya adalah sabun. Sabun merupakan salah satu barang yang memiliki harga yang relatif murah dan dengan kategori low involvement, ketika melakukan pembelian, konsumen tidak harus memikirkan masak-masak sebelum melakukan pembelian. Hal ini tentu saja akan berbeda ketika konsumen akan membeli sebuah barang elektronik. Konsumen akan menimbang-nimbang masalah kualitas, merek, garansi, ketahanan produk, layanan purna jual, dan sebagainya. Karena kemudahan "berpindah ke lain hati" inilah, ULI sebagai perusahaan FMCG, harus banyak belajar bagaimana cara mempertahankan konsumen agar loyal dalam mengkonsumsi produk-produk ULI dan juga memperhatikan kompetitor sejenis di pasar.

Ketiga, ULI memiliki banyak bright talents sehingga banyak pengetahuan yang harus dibagikan kepada orang lain. Pengetahuan yang dimiliki setiap bright talent yang ada akan jauh lebih bermanfaat jika dibagikan kepada orang lain dalam perusahaan, sehingga pengetahuan tersebut juga menjadi pengetahuan organisasi atau perusahaan, bukan hanya menjadi pengetahuan individu saja.

Keempat, ULI merupakan sebuah perusahaan yang besar namun tetap bisa lincah dan responsif dalam menghadapi perubahan yang terjadi. Hal ini dapat digambarkan oleh seekor gajah yang sedang menari. Kenapa gajah? Seperti diketahui, gajah adalah salah satu binatang bertubuh sangat besar, dan mustahil untuk menari, karena ukuran badannya tersebut. Seperti layaknya gajah, ULI merupakan sebuah perusahaan FMCG yang besar, namun ULI ingin tetap lincah dan bisa menari, yaitu lincah dan responsif terhadap perubahan yang akan terjadi di lingkungan bisnis.

Dan terakhir, budaya belajar merupakan salah satu fondasi dari Knowledge Management. Kesuksesan ULI dalam menjalankan knowledge management telah menghasilkan sebuah penghargaan Most Admired Knowledge Enterprise (MAKE) Award di tahun 2005, 2006, 2007 untuk tingkat Indonesia dan 2008 untuk tingkat Asia.

Setiap individu memiliki pengetahuan dan pengalaman tersendiri, dan jika dia bagikan pengetahuan dan pengalamannya tersebut kepada orang lain maka akan tercipta performance secara individu. Pengetahuan dan pengalaman yang didistribusikan kepada orang lain dalam organisasi akan menciptakan organization knowledge, sehingga terjadi transformasi. Transformasi yang dimaksud di sini adalah transformasi pengetahuan dan pengalaman dari seseorang (individual) ke perusahaan (organization). Melalui kegiatan sharing ini, akan memberikan dampak yang sangat kuat (powerful) bagi perusahaan karena tercipta hubungan emosional antara orang-orang yang ada dalam perusahaan. Ketika tercipta hubungan emosional ini, maka orang-orang dalam perusahaan memiliki keinginan yang kuat pula untuk memajukan perusahaan bersama-sama.

Berbagai jenis dan bentuk perusahaan yang ada saat ini. Ada yang disebut one-manned company, dimana perusahaan ini didirikan, dimiliki dan dikelola oleh seorang diri. Kelebihan dari perusahaan ini adalah fleksibel dan adaptif terhadap lingkungannya. Namun, perusahaan yang seperti ini juga memiliki kekurangan, yaitu perusahaan ini cenderung lemah dalam menjalankan kegiatan bisnisnya, karena dijalankan oleh seseorang saja. Selanjutnya ada small company, yaitu perusahaan kecil yang didirikan dan dikelola oleh sedikit orang, yang memiliki cukup kekuatan dalam menjalankan kegiatan bisnisnya, dimana karyawan di dalamnya saling terhubung satu sama lain, fleksibel, cepat dan tentu saja lincah. Keputusan di dalam perusahaan ini relatif cukup cepat diambil. Ada juga jenis big company, yang merupakan perusahaan besar, terdiri dari banyak orang di dalamnya. Jumlah karyawan yang cukup banyak di perusahaan yang besar membuat mereka tidak saling terhubung satu sama lainnya. Ciri perusahaan ini adalah kuat, namun kelemahannya adalah 
kaku, lamban dan berumur pendek. Kenapa perusahaan besar justru berumur pendek? Kadangkala, perusahaan besar merasa bahwa dirinya sudah paling hebat dengan "kebesarannya", namun ia lupa untuk melakukan upaya untuk menjadi lebih besar lagi, dan inilah yang menghambat berkembangnya suatu perusahaan dan akan mempercepat kemunduran suatu perusahaan. Jenis perusahaan yang terakhir, yaitu big company with soul of small company adalah jenis perusahaan yang paling diharapkan. Perusahaan ini kuat, cepat, lincah, fleksibel dan tentu saja berumur panjang. Karyawan yang ada di perusahaan ini saling terhubung satu sama lain, termasuk jalan pikiran yang dimilikinya. Ketika si A memiliki suatu keinginan, keinginan tersebut juga dimiliki si B demi kemajuan perusahaan. Perusahaan jenis ini yang akan bertahan dan mampu mengatasi perubahan lingkungan bisnis yang ada.

\section{Tiga Pilar Sharing}

Dalam proses menciptakan budaya sharing, ada tiga pilar yang menjadi dasar utama yakni:

\section{Contributor}

Tugas perusahaan adalah bagaimana menciptakan suasana yang mendukung para karyawannya untuk membagikan sharing ke dalam organisasinya. Selain itu, perusahaan juga menciptakan keinginan dan semangat karyawannya untuk bisa sharing dengan orang lain.

\section{Audience}

Jika tidak ada orang yang mau menjadi audience untuk mendengarkan sharing, proses ini tidak akan berjalan lancar. Oleh sebab itu, para audience juga harus dididik untuk memiliki semangat dan passion untuk ikut belajar tentang pengetahuan dan pengalaman dari orang lain.

\section{Medium for Sharing}

Belajar dapat dilakukan dimana dan kapan saja, maka pemilihan medium untuk proses ini harus dibuat unik dan berbeda dari yang sudah ada sehingga memotivasi para karyawan untuk melakukan sharing.

\section{Sharing Building Blocks}

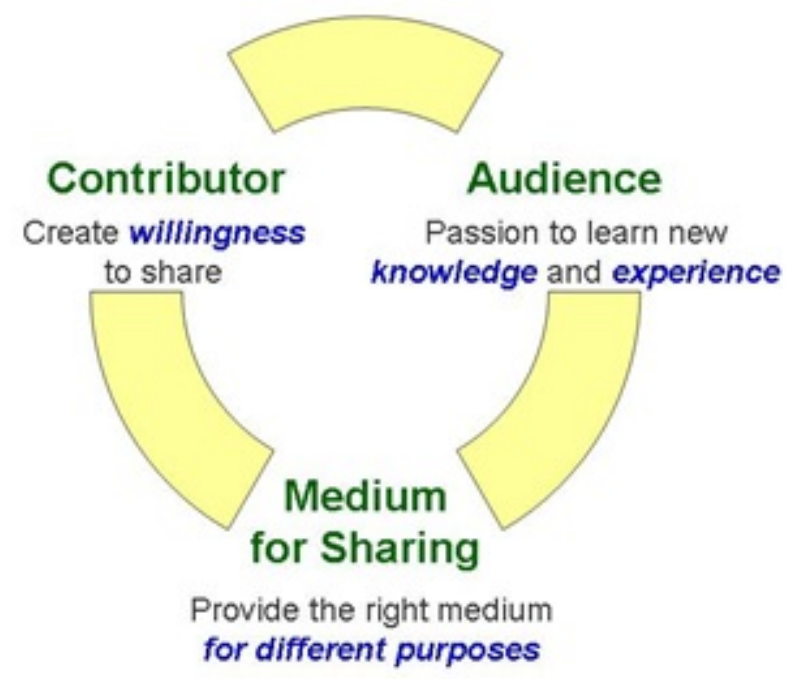

Gambar 3. Tiga Pilar Sharing di Unilever 


\section{Pendekatan Program Pembelajaran (Learning) dan Knowledge Management di Unilever Indonesia}

Salah satu pendekatan yang dilakukan oleh ULI dalam learning dan knowledge management adalah adanya learning award. Ini merupakan sebuah program yang dirancang perusahaan untuk memotivasi para karyawan untuk melakukan sharing dan mengikuti proses pembelajaran, memfasilitasi kegiatan tersebut dengan semenarik mungkin dan tentu saja memberikan apresiasi kepada para karyawan yang telah mengikuti kegiatan tersebut dengan baik. Learning award ini juga bertujuan untuk mengembangkan budaya sharing dan menciptakan internal trainer di dalam perusahaan.

Alasan munculnya Learning Award adalah adanya temuan perusahaan bahwa selama ini di dalam perusahaan, karyawan hanya mengetahui apa yang menjadi pekerjaan di departemennya saja, tidak mengerti mengenai departemen lain dalam perusahaannya. Oleh sebab itu dibutuhkan sebuah sistem yang dapat membuat suatu kesatuan antar departemen agar sinergi dalam mencapai tujuan perusahaan.

Selain itu temuan yang lain adalah bahwa seorang asisten manajer atau asisten supervisor yang ingin belajar banyak dari atasannya, justru tidak mendapat dukungan dari atasannya. Hal inilah yang mendorong terciptanya learning award agar terjadi komunikasi atau proses pembelajaran oleh seluruh lapisan karyawan, baik atasan maupun anak buahnya.

Beberapa contoh kegiatan yang telah dilakukan ULI dalam mengimplementasikan budaya sharing adalah sebagai berikut ini :

1. Knowledge sharing $\rightarrow$ sharing suatu pengetahuan yang relatif cukup mendalam.

\section{Knowledge Club}

Sebuah talkshow yang menghadirkan seorang pembicara dan seorang moderator. Pembicara biasanya berasal dari top management dan melakukan sharing mengenai topik atau tema tertentu.

\section{Retrospect}

Merupakan sebuah cara untuk mengambil pelajaran dari sebuah kejadian di masa lalu. Misalnya, ketika sebuah proyek ULI yang gagal di pasar, maka dengan membaca retrospect ini, karyawan jadi mengetahui apa saja yang menyebabkan kegagalan dan dapat belajar dari kegagalan tersebut.

\section{Enterprise Award}

Sebuah kegiatan seperti lomba, dimana para karyawan ditantang untuk membuat sebuah tim kecil yang anggotanya terdiri dari orang-orang yang berasal dari departemen yang berbeda-beda. Tim ini harus memberikan masukan atau project baru bagi perusahaan dan project tersebut memberikan keuntungan bagi perusahaan hingga batas nominal tertentu. Project tersebut dipresentasikan di depan para Board of Directors (BOD). Bagi para pemenang, disediakan hadiah paket jalan-jalan keliling Eropa.

Contohnya adalah sebuah tim yang mampu menemukan jalur distribusi barang-barang yang efektif dan efisien dari Surabaya ke Papua. Dengan adanya project ini, maka perusahaan dapat meminimalkan biaya distribusi barang-barang tersebut.

\section{Informal Sharing}

\section{Solar (Share of Learning and Result)}

Program ini dirancang agar siapa saja bisa memberikan sharing pengetahuan dan pengalaman terutama yang berkaitan pekerjaan atau mendukung seseorang untuk berkarya lebih baik lagi. Selain memanfaatkan kontributor dari para internal trainer di perusahaan juga sesekali mengundang pembicara tamu. Misalnya, dengan tema tagihan kartu kredit, kemudian seorang karyawan yang pernah menjadi korbannya, memberikan sharing tersebut di hadapan karyawan yang lain. 


\section{. Glad (Group Learning and Development)}

Adalah proses sharing dari karyawan yang lebih senior kepada adik-adiknya tentang dunia kerja, pengalaman pribadi, maupun tips-tips dalam menjalani tantangan di pekerjaan maupun kehidupan pribadi. Dengan lain kata, forum ini lebih bersifat seperti coaching, sebuah diskusi dengan pembicara yang dituakan.

\section{Cinemania}

Seseorang karyawan diberi tiket menonton gratis dan setelah menonton, ia harus menceritakan tentang film yang dia tonton dan mengambil insight dari film tersebut.

\section{Videocafe}

Sebuah program unik di mana para peserta menyaksikan program video interaktif tentang berbagai topik pengembangan diri sambil menikmati kopi hangat yang membangkitkan selera. Diskusi bisa dilakukan di sebuah kafe, seperti Starbucks, sambil ngopi, untuk melihat video dan membahas tema tertentu.

\section{Book Club}

Dirancang agar karyawan yang gemar membaca mendapat wadah untuk memberikan sharing kepada karyawan lainnya tentang pelajaran dan ilmu yang didapat dari buku-buku yang pernah dibacanya.

\section{Online Sharing}

\section{K-Club Online}

Merupakan knowledge club dengan versi online agar lebih mudah diakses oleh seluruh pihak.

\section{Online Library}

Perusahaan memiliki perpustakaan dengan koleksi buku yang banyak dan bagus, dan dapat dengan mudah dipinjamkan kepada seluruh karyawan ULI, dengan mengisi formulir tertentu secara online. Setelah itu, buku akan dikirim ke karyawan tersebut. Sistem ini terinspirasi oleh amazon.com, yaitu situs penjualan buku secara online. Selain itu, banyak juga terdapat e-book yang dapat dengan mudah di-download.

. Interactive Online Training

Sebuah training yang dirancang dengan online.

\section{Other Sources}

Books

Journals

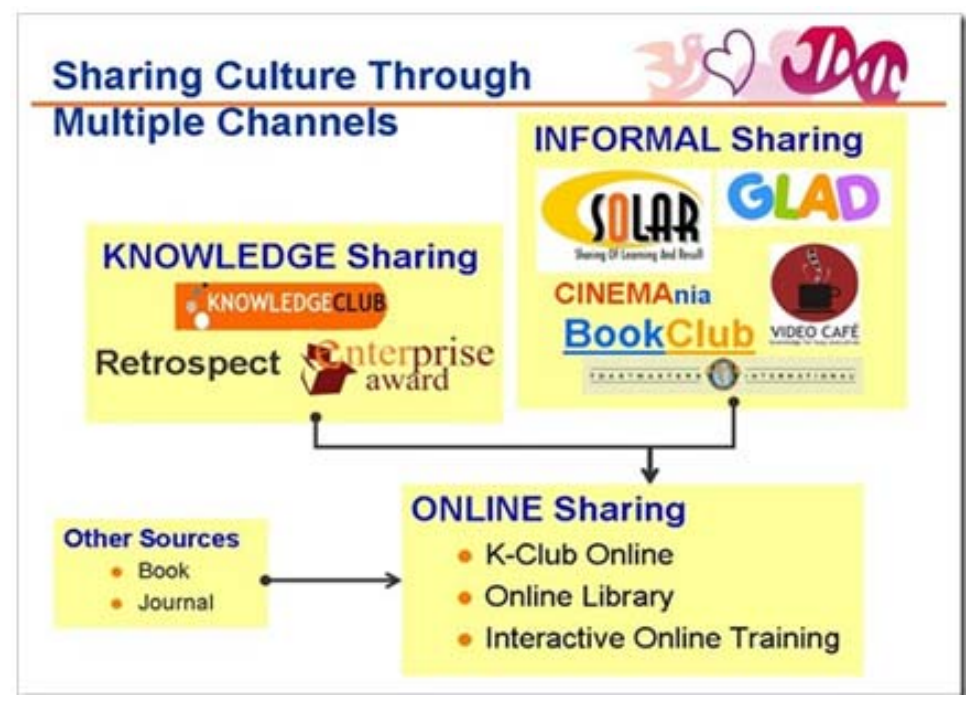

Gambar 4. Budaya Sharing di Unilever 


\section{Program Reward Knowledge Management}

Untuk memotivasi karyawan agar mau mengikuti kegiatan-kegiatan perusahaan yang berhubungan dengan learning organization dan knowledge management adalah dengan memberikan hadiah bagi trainer dan audience-nya. Bagi para audience, diberikan penghargaan tertentu seperti yang paling sering datang dan datang tepat waktu. Hal ini juga dilakukan untuk menciptakan budaya disiplin di kalangan karyawan.

Sementara itu, bagi seseorang yang menjadi internal trainer atau menghasilkan modul akan dinilai oleh para peserta training tersebut, kemudian akan divalidasi oleh Departemen Learning. Poin yang sudah dikumpulkan diakumulasikan untuk mendapatkan hadiah tertentu, seperti perjalanan wisata ke luar negeri, barang-barang elektronik seperti laptop, kamera digital, mini compo dan lainlain. Selain itu, juga terdapat beberapa penghargaan yang diberikan kepada para karyawan yang telah mendapatkan nilai/skor tertentu yang berupa: Learning Champion of The Year, Coach of The Year, The Most Active Contributor, The Most Values Contributor, Top Scorer Award.

Tujuan diadakan penghargaan seperti ini adalah untuk menghargai para internal trainer yang telah melakukan sharing dan juga untuk memotivasi seseorang untuk melakukan sharing.

Penghargaan yang paling bermakna kepada para trainer yang telah meluangkan waktu untuk membagikan pengetahuan kepada karyawan lain adalah dengan mendapatkan penghargaan dalam bentuk immaterial, seperti rasa bangga yang dimiliki karena modulnya dibaca oleh seluruh karyawan ULI di seluruh Indonesia.

Sepintas program ini terlihat mahal, akan tetapi justru cost untuk external trainer dapat dikurangi dengan adanya internal trainer tersebut. Program ini semakin memberikan keuntungan tersendiri bagi perusahaan. Perusahaan dapat meminimalkan biaya yang harus dikeluarkan untuk kegiatan training, dan juga dapat mengembangkan para karyawannya lebih baik lagi, dengan menjadi internal trainer.

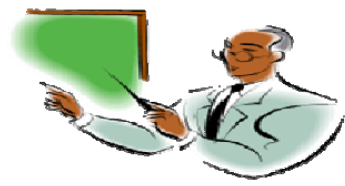

Trainer/modul

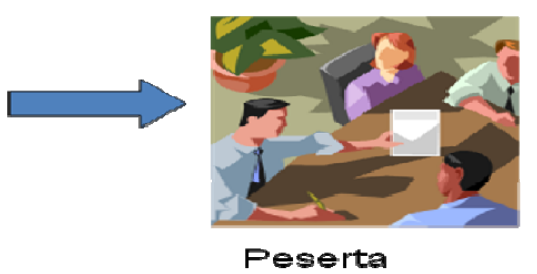

Peserta

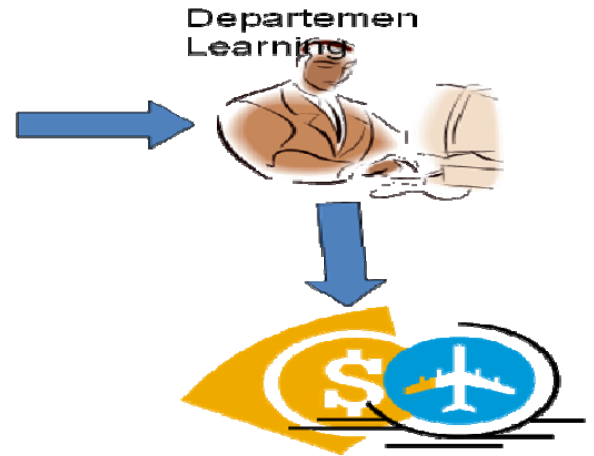

Gambar 5. Proses Reward KM Unilever

\section{Best Practice Knowledge Management di Unilever}

- Kegiatan learning organization dan knowledge management dilakukan di luar jam kerja

Kegiatan learning organization dan knowledge management ini dilakukan di luar jam kerja. Misalnya, seorang karyawan yang memiliki shift bekerja pada jam 2 siang, pada jam 12 siangnya, dia dapat datang ke kantor untuk proses belajar terlebih dahulu. Jadi, pada prinsipnya, perusahaan memperbolehkan kapan saja karyawannya untuk mengikuti proses pembelajaran, ketika karyawan tersebut sedang tidak ada pekerjaan tentunya. Contohnya seperti yang ada di Head Office ULI di Jakarta. Disana, karyawan yang ingin belajar, menggunakan waktunya setelah jam kerja berakhir, untuk mendatangi perpusatakaan atau mengikuti kegiatan-kegiatan pembelajaran yang telah dirancang. - Penyediaan matriks internal training yang sistematis

Jika dihitung secara matematis, jam kerja tentu saja akan terbuang percuma ketika setiap hari karyawan mengikuti training. Akan tetapi hal ini tidak akan terjadi, karena ULI telah memiliki sebuah 
matriks internal training, yaitu berupa jadwal yang menunjukkan kapan saja training tersebut diadakan, siapa saja yang menjadi pesertanya dan juga apa saja yang menjadi materi training tersebut. Training ini tidak selalu diadakan setiap hari sehingga tidak akan merugikan waktu kerja karyawan.

Pendekatan yang dilakukan Head Office lebih universal. Maksudnya adalah belajar merupakan sebuah investasi perusahaan. Perusahaan yakin bahwa dengan belajar, karyawan dapat menghasilkan output yang lebih besar dan tentunya hal ini akan menguntungkan perusahaan.

- Komitmen dari para manajerial untuk memberikan coaching

Bagi orang yang memiliki jabatan lebih tinggi atau lebih senior, memberikan panduan atau arahan kepada anak buahanya atau yang lebih junior (coaching system). Selain itu ada komitmen atau keharusan bagi para manajerial untuk memberikan arahan kepada bawahannya sejumlah 12 coaching setiap tahun. Sang bawahan berhak untuk menagih ke atasannya apabila sang atasan belum menyampaikan coaching seperti yang telah ditentukan.

- Menghilangkan perasaan ragu terhadap kerahasiaan informasi

Hal-hal yang bersifat internal perusahaan memang bukan bersifat rahasia bagi para karyawan ULI. Oleh sebab itu, hal yang berhubungan dengan internal perusahaan dapat di-share kepada seluruh karyawan ULI. Akan tetapi ada beberapa hal yang memang bersifat confidential dan memang hanya diketahui oleh kalangan terbatas di dalam perusahaan. Pada intinya, hilangkan perasaan ragu atas halhal yang mana yang bersifat rahasia dan yang bukan, karena perasaan ragu inilah yang justru akan menghambat proses sharing tersebut. Perusahaan juga memberikan kepercayaan kepada karyawannya untuk mengetahui hal-hal apa saja yang ada di internal perusahaan untuk dibahas dalam sharing, dengan harapan informasi ini akan membantu proses sharing agar berjalan dengan lancar. Dari sharing ini, diharapkan para karyawan dapat mengambil insight tersendiri dan belajar dari adanya sharing ini.

\section{Dampak Penerapan Knowledge Management di Unilever}

Apa yang telah dilakukan ULI selama ini dalam menciptakan dan memfasilitasi budaya sharing melalui kegiatan-kegiatan yang telah disebutkan seperti di atas, memberikan beberapa hasil yang sangat menggembirakan. Dari data yang diperoleh (Noer, 2009), dari 2 pabrik ULI di Cikarang dan Rungkut, terdapat fakta bahwa 1 dari 4 pekerja pabrik menjadi seorang internal trainer. Materi yang dibawakan tentu saja berbeda-beda antara orang yang satu dengan orang yang lain. Materi-materi ini dibukukan dalam bentuk sebuah modul, yang jumlahnya ada sekitar 250 modul. Modul tersebut tentu saja dibuat oleh para pekerja (internal trainer) dan untuk memudahkan karyawan lainnya untuk belajar, maka modul-modul ini juga tersedia secara online, sehingga memudahkan seluruh karyawan untuk mengaksesnya dan memudahkan mereka untuk mengikuti proses belajar. Dengan informasi dan data ini membuktikan bahwa di ULI, budaya sharing dan belajar telah dijalankan dengan baik. Selain itu, ULI juga mendapatkan penghargaan tingkat dunia, yaitu Most Admired Knowledge Enterprise (MAKE) Award pada tahun 2005-2007 untuk tingkat Indonesia dan 2008 untuk tingkat Asia.

Budaya belajar di dalam perusahaan dapat dibangun dan dikembangkan, asalkan ada keinginan dari seluruh pihak, baik dari para karyawan maupun perusahaan itu sendiri. Perusahaan sebagai fasilitator berkewajiban untuk menyediakan fasilitas pembelajaran bagi seluruh karyawan yang telah memiliki keinginan untuk belajar. Perusahaan sebagai fasilitator menciptakan training semenarik mungkin dan fun, agar tidak terasa jika sedang belajar. Training atau kegiatan yang berhubungan denagn kegiatang learning dan sharing dapat dilaksanakan berdasarkan ide-ide yang datang dari para karyawan. Jika ide tersebut realistis dan mampu dijalankan, perusahaan hanya memfasilitasinya saja. Setiap orang memiliki pola atau cara belajar yang berbeda-beda. Oleh sebab itu, untuk mempermudah proses belajar bagi seluruh karyawan, maka perusahaan sebaiknya membuat proses belajar dapat dilakukan dengan mudah. Untuk menarik keinginan para karyawan untuk mengikuti segala kegiatan pembelajaran, maka dibutuhkan usaha "provokatif" secara positif untuk menarik perhatian para karyawan untuk mengikuti sharing dan proses belajar. 
Tentunya promosi yang provokatif ini dalam konteks positif di mana perusahaan harus bisa memasarkan kegiatan tadi lewat pengumuman, poster, teaser komputer maupun berbagai media komunikasi dengan gambar dan pesan yang memiliki kekuatan sehingga karyawan tertarik untuk mengikutinya. Tanpa adanya promosi kegiatan yang efektif, bisa jadi berbagai kegiatan yang telah dirancang dengan susah payah tadi tidak mencapai hasil maksimal yang diinginkan.

Belajar yang efektif adalah proses belajar yang datang dari keinginan seseorang, bukan karena adanya paksaan dari perusahaan. Ketika seseorang mengikuti training karena "perintah" dari perusahaan, maka pengetahuan yang ia dapatkan hanya sia-sia karena akan menguap begitu saja, karena ia telah melaksanakan kewajibannya terhadap perusahaan. Akan tetapi, jika keinginan tersebut datang dari keinginan pribadi, maka yang akan terjadi adalah karyawan tersebut lebih mendapatkan "insight" dari kegiatan training yang ia ikuti.

Bagi para karyawan yang telah memberikan sharing atau menjadi trainer dalam kegiatankegiatan tersebut akan mendapatkan reward yang bertujuan untuk menghargai hasil jerih payah mereka dan juga untuk memotivasi orang lain untuk melakukan hal yang sama. Jika diukur dengan nominal uang, maka reward ini memang tidak seberapa nilainya. Akan tetapi nilai immaterial yang terdapat di dalam reward tersebut jauh lebih berharga. Ketika seorang internal trainer yang merupakan level operator di pabrik, mendapatkan ucapan langsung (jabat tangan) dari CEO perusahaan secara langsung, maka ia akan merasa sangat bangga dan merasa dihargai. Hal ini akan memotivasinya untuk menghasilkan karya yang lebih baik lagi dan meningkatkan keinginannya untuk menjadi internal trainer kembali, tentunya dengan materi training yang berbeda dari sebelumnya. Kebanggaan yang lain adalah nama internal trainer yang bersangkutan akan menjadi terkenal di kalangan seluruh karyawan ULI sebagai orang yang telah memberikan kontribusi nyata ke perusahaan. Penghargaan yang tidak dapat diukur dengan uang akan memberikan kesan yang jauh lebih mendalam di benak para internal trainer tersebut.

\section{SIMPULAN}

Pada akhirnya, knowledge yang dimiliki perusahaan, menciptakan performance baik secara individu maupun perusahaan, kemudian akan menciptakan sustainable growth bagi perusahaan. Pertumbuhan perusahaan yang berkelanjutan inilah yang diharapkan oleh seluruh perusahaan dalam menjalankan kegiatan bisnisnya.

Dari pemaparan di atas, ada beberapa kunci sukses yang perlu menjadi rujukan bagi perusahaan atau organisasi mana saja yang memang sungguh-sungguh berkeinginan membangun budaya belajar: Belajar harus menyenangkan dan membuat orang merasa terlibat (engaging), Sediakan media pembelajaran yang beragam untuk mengakomodir kebutuhan belajar yang berbeda-beda dari karyawan, Pastikan sumber-sumber untuk belajar tersedia dan mudah diakses oleh siapa saja Komunikasikan kegiatan belajar dengan menarik dan "provokatif", Pemimpin memberikan teladan dengan memfasilitasi sekaligus terlibat dalam kegiatan pembelajaran, Ciptakan kegiatan belajar sebagai ways of working perusahaan, Belajar harus menjadi kebutuhan dan tanggung jawab pribadi setiap karyawan untuk pengembangan diri mereka masing-masing, Internal trainer yang mengembangkan modul-modul pembelajaran perlu diperluas untuk menjangkau level officer ke atas, bukan hanya di level staff saja, Unilever dapat mengembangkan pengalaman mereka mengembangkan budaya belajar dan knowledge management ke organisasi yang lain dalam bentuk lembaga training. Selain lembaga tersebut bersifat profit centre juga dapat memberikan nilai lebih dari misi sosial dan semakin meningkatkan prestise Unilever di dunia usaha. 


\section{DAFTAR PUSTAKA}

Hapsari, J. (2009). Building Learning Culture. (http://www.ui.ac.id/building-learning-culture) diakses tanggal 25 Mei 2010.

Noer, M. (2009). Case Study Unilever. (http://www.muhammadnoer.com/unilever) diakses tanggal 25 Mei 2010

Tobing, P. L. (2007) Knowledge Management; Konsep, Arsitektur dan Implementasi, Yogyakarta: Graha Ilmu

Senge, P (1990) The Fifth Discipline : The Art And Practice

Munir, N. (2008). Knowledge Management Audit, Sekolah Tinggi Manajemen PPM

Widayana, L. (2005) KNOWLEDGE MANAGEMENT - Meningkatkan Daya Saing Bisnis, Bayu Media Publishing. 